\title{
Inhibitory Effect of Marine Mangrove on the Growth of Alternaria solani Causing Tomato Early Blight Disease
}

\author{
G. Mahalakshmi, L. Vengadeshkumar*, S. Sanjaygandhi and A. Mary Sharmila \\ Department of Plant Pathology, Faculty of Agriculture, Annamalai University, \\ Annamalai Nagar, Chidambaram, Tamil Nadu, India-608 602 \\ *Corresponding author
}

\section{Keywords}

Tomato, Alternaria solani, Rhizophora apiculata, in vitro

\section{Article Info}

Accepted:

18 March 2020

Available Online:

10 April 2020

\section{A B S T R A C T}

Tomato is one of important vegetable crop cultivated in worldwide. Among the diseases which causing tomato early blight caused by Alternaria solani is serious disease. The present investigation was undertaken to assess the bio-efficacy of mangroves at different concentrations against Alternaria solani causing tomato early blight disease under in vitro condition. Among the five mangrove species were tested, the higher antifungal activity was observed with $20 \%$ of Rhizophora apiculata recorded minimum mycelial growth, sporulation and germination of spore $(4.82 \mathrm{~mm}, 14.46 \mathrm{~mm},+$ and $5.86 \%)$ of Alternaria solani under poisoned food technique, agar well method and spore germination assay respectively, which was followed by Rhizophora annamalayana, Avecinia officinalis, Rhizophora mucronata and Avecinia marina. While the least antifungal activity was observed with the species of Avicenia marina recorded $(18.23 \mathrm{~mm}, 35.64 \mathrm{~mm}$, ++ and $16.23 \%$ ) Significant inhibitory activity was also observed in 5, 10 and $15 \%$ concentration in all the three methods.

\section{Introduction}

Tomato (Lycopersicon esculentum Mill.) is one of the most widely grown vegetable in the world. It is a small annual or short livedperennial herb belonging to the family solanaceae. Tomato ranks second next to potato in world acreage but it ranks first among processing crops. In Tamil Nadu, it is cultivated throughout the year during rainy, winter and summer seasons and occupies an area of 38.73 lakh ha with production of 840.32 million tonnes in 2016-2017 (Indian Horticulture Database, 2017).

Early blight caused by A. solani (Ellis and Martin) Jones and Grout, is one of the most catastrophic and frequently occurring disease of the crop (Jones et al., 1991). The yield loss due to this disease ranged between 50 to $86 \%$ in fruit yield (Mathur and Shekhawat, 1986). The antimicrobial compounds in plants are 
being used bio-pesticide are eco-friendly nature and a best alternative for minimizing the usage of chemical pesticide in agriculture. Also, it has alkaloids and essential oil was showed antifungal, antibacterial, insecticidal, nematicidal, herbicidal and antiviral activities (Hosein et al., 2010; Chang et al., 2012; Kordali et al., 2013; Kepenekci and Saglam, 2015).

The antifungal activity of some mangrove species has been well documented against plant pathogens viz., Avicennia marina against Alternaria citri, Avicennia marina and Rhizophora mucronata against A. alternata, Rhizophora apiculata against Macrophomina phaseolina (Mehdi et al., 2000; Muthukumar et al., 2014; Behbahani et al., 2016; Rastegar and Mohsen Gozan, 2016). More than 200 bioactive compounds were identified from mangroves with antibacterial and antifungal properties belong to steroids, triterpenes, saponins, flavonoids, alkaloids, tannins and phenolics (Bandaranayake, 2002; Bose and Bose, 2008; Chandrasekaran et al., 2009; Vengadeshkumar, 2017). Hence, the present study was undertaken to assess the bioefficacy of certain mangrove species against A. solani under in vitro condition.

\section{Materials and Methods}

In our previous study, an intensive fixed plot survey was conducted in major vegetable growing districts in Tamilnadu, India during 2017 and infected leaf sample was isolated and identified as $A$. solani named as $\mathrm{AS}_{1}$ to $\mathrm{AS}_{10}$. Further, all the isolates were tested for their growth and ability of virulent, among the isolates tested, isolate $\mathrm{AS}_{5}$ was found to be most virulent and showed better in their growth under in vitro experiments. Hence, based on our previous study the isolate $\mathrm{AS}_{5}$ was selected and used as test pathogen in the present study.

\section{Collection and authentication of mangrove}

The fresh leaves of marine mangroves were collected from Pichavaram Mangrove forest, Tamil Nadu and authenticated in the herbarium of C.A.S. in Marine Biology, Annamalai University, Parangipettai, Tamil Nadu, India. The leaves were carefully examined and healthy leaves were washed, shade dried, coarsely powdered and stored in air tight bottles for further work. The list of mangrove species used in this study was given below:

\begin{tabular}{|c|l|c|}
\hline S.No & \multicolumn{1}{|c|}{ Mangroves } & Parts used \\
\hline 1. & Avicenia marina & Leaves \\
\hline 2. & Avicenia officinalis & Leaves \\
\hline 3. & Rhizophora apiculata & Leaves \\
\hline 4. & $\begin{array}{l}\text { Rhizophora } \\
\text { annamalayana }\end{array}$ & Leaves \\
\hline 5. & Rhizophora mucronata & Leaves \\
\hline
\end{tabular}

\section{Preparation of aqueous extract}

The freshly collected leaf materials were separately washed with tap water, then with alcohol and finally with repeated changes of sterile distilled water. They were separately ground in sterile distilled water at the rate of one $\mathrm{ml} / \mathrm{g}$ of leaf tissue in a sterilized pestle and mortar.

The extract was stained through two layer of muslin cloth subsequently filtered through Whatman No:1 filter paper and centrifuged @ $1500 \mathrm{rpm}$ for $10 \mathrm{~min}$. This formed the standard plant extract (100\%) solution (Shekhawat and Prasad, 1971). This extract was further diluted to the desired concentration $(5,10,15 \& 20 \%)$ by adding requisite quantities of sterile distilled water and tested against pathogen. 


\section{In vitro efficacy of marine mangrove}

\section{Poisoned food technique (Narender Kumar et al., 2017)}

Potato dextrose agar PDA medium mixed separately with extracts of different plant species at different concentrations viz., 5, 10, 15 and $20 \%$ poured into sterile petri dishes, allowed to cool and solidify. Mycelial disc $(9 \mathrm{~mm})$ of 15 days old culture of test pathogen placed at the centre of the petri dishes and incubated at $28 \pm 2^{\circ} \mathrm{C}$ for 10 days. The PDA medium with the same concentration of sterile distilled water alone served as control. Similarly a fungicide viz., mancozeb $(0.25 \%$ conc.) as also tested against the pathogen for comparison for each treatment. The experiments was replicated thrice and the per cent inhibition of mycelial growth if any was determined by the formula

$\mathrm{PI}=\mathrm{C}-\mathrm{T} / \mathrm{C} \times 100$

(Where, $\mathrm{C}=$ Diameter of $A$. solani in control, $\mathrm{T}=$ Diameter of $A$. solani in treated)

\section{Agar well method}

The antimicrobial activity of mangroves against $A$. solani was tested by agar well method (Thongson et al., 2004). Spore suspension of the test pathogen was preparedwith sterile distilled water from 15 days old culture. Desired concentrations of the selected plant extracts were prepared. $20 \mathrm{ml}$ of PDA medium was seeded with $3 \mathrm{ml}$ of spore suspension $\left(1 \times 10^{6}\right.$ spore $\left./ \mathrm{ml}\right)$ and poured into a Petri plate and allowed to solidify. Four wells were made equidistantly with the aid of sterile cork borer. Test plant extracts of different concentrations were pipetted out separately poured into each well. Mancozeb @ $0.25 \%$ conc. was used for comparison. Suitable control was maintained for each treatment. The plates were incubated at $28 \pm 2^{\circ} \mathrm{C}$ and the inhibition zone of the fungal growth around each well was recorded.

\section{Spore germination assay}

To test the spore germination of pathogen, two drops of each extracts at 5, 10, 15 and 20 per cent concentration along with spores were placed in a cavity slide and incubated at $28 \pm 2^{\circ} \mathrm{C}$ for 24 hours and thereafter sporulation and germination of spores was assessed and recorded. The most effective mangrove species ( $R$. apiculata) is identified from above studies was further tested against the growth of $A$. solani with different solvents by poisoned food technique is already described. Three replications were maintained for each treatment.

\section{Results and Discussion}

Antifungal activity of mangroves at different concentration on growth of $A$. Solani $\mathrm{AS}_{5}$ (Poisoned Food Technique)

Five species of mangroves were tested at different concentration (5, 10, 15 and 20\%) against the test pathogen. In general, the inhibition of growth of fungus increased with an increase in concentration of the aqueous extract of the test plants. Among the plant extracts tested, $R$. apiculata at $20 \%$ conc. showed significantly the highest reduction on the mycelial growth of test pathogen with $4.82 \mathrm{~mm}$ (93.97\% of growth reduction) as against $80.00 \mathrm{~mm}$ in control treatment.

This was followed by twenty percent extract of $R$. annamalayana, $A$. officinalis, $R$. mucronata and $A$. marina with a growth reduction of $88.60,85.67,81.36$ and $77.21 \%$ in the decreasing order of merit respectively. Mancozeb $75 \%$ WP $(0.25 \%)$ used for comparison completely inhibited the growth and accounted for $100 \%$ growth reduction of the test pathogen (Table 1). 
Antifungal activity of mangroves at different concentration on growth of $A$. solani $\mathrm{AS}_{5}$ (agar well method)

All the mangrove extracts at different concentration viz., 5, 10, 15 and 20 per cent were found to be effective in against $A$. solani. Among the plant extract tested, aqueous extract of $R$. apiculata at $20 \%$ conc. inhibited the growth of pathogen with minimum mycelial growth $(14.46 \mathrm{~mm})$ which accounting $81.92 \%$ inhibition over control.

This was followed by the extract of $R$. annamalayana (79.61\%), A. officinalis (73.45\%), R. mucronata $(63.38 \%)$ and $A$. marina $(55.45 \%)$ in the decreasing order of merit. The standard chemical fungicide Mancozeb $75 \% \mathrm{WP}$ at $0.25 \%$ conc. showed 91.92 per cent inhibition of the test pathogen. The control treatment was recorded with mycelial growth of $80.00 \mathrm{~mm}$ (Table 2).

Antifungal activity of mangroves at different concentration on sporulation and spore germination of $A$. Solani $\mathrm{AS}_{5}$ (spore germination assay)

With regard to the sporulation and spore germination, $R$. apiculata at $20 \%$ concentration showed significantly poor sporulation (+) and highest reduction in spore germination $(5.86 \%)$ as against excellent sporulation $(++++)$ and maximum spore germination $(80.00 \%)$ in control.

This was followed by twenty per cent extract of $R$. annamalayana (8.46\%), A. officinalis (11.17\%), R. mucronata (15.19\%) and $A$. marina $(16.23 \%)$ in the reduction of spore germination with the decreasing order of merit (Table 3).

The results obtained with $20 \%$ conc. of aqueous extract of $R$. apiculata were almost similar with the result obtained with $15 \%$ conc. in reducing fungal growth in all the three experiments (Table 1, 2 and 3).

In the present study the mangrove extracts showed varying degree of growth inhibition against $A$. solani. The inhibition of growth of fungus increase with an increase in concentration of the aqueous extract of test plants. Among the mangrove species tested against A. solani, R. apiculata @ 20\% conc. showed significantly highest reduction in the radial growth, biomass production, sporulation and spore germination of the pathogen under in vitro condition. $R$. annamalayana is a next best mangrove to inhibit the growth of test pathogen. However, the results obtained with $20 \%$ conc. of $R$. apiculata almost similar to the results obtained with $15 \%$ conc. of $R$. apiculata.

Similar to the present study, Rasteger and Gozari (2016) reported that $R$. Apiculata exhibited antifungal principles while against Penicillium sp. and A. alternata. Likewise, the leaf extracts of $R$. apiculata showed antifungal compounds against fungal pathogen M. phaseolina (Muthukumar et al., 2014).

The extract of Ceriops decandra showed maximum inhibition against Candida albicans (Selvam and Kolanjinathan, 2014). Ethanolic extract of mangrove species $A$. marina was found to inhibit the radial growth of $M$. phaseolina under in vitro was reported (Mehdi et al., 1999). Various workers reported that antimycotic activity of botanicals viz., Barbeya oleoides, Maerua oblongifolia, A. sativum and Mentha arvensis against A. solani, Botrytis fabae, Fusarium solani, Phytophthora infestans and Aspergillus niger (Baka, 2010; Taskeen-UnNisa et al., 2011; Raji and Raveendran, 2013). 
Table.1 Antifungal activity of mangroves at different concentration on growth of $A$. solani $\mathrm{AS}_{5}$ (Poisoned Food Technique)

\begin{tabular}{|c|c|c|c|c|c|c|c|c|c|}
\hline \multirow[t]{2}{*}{$\begin{array}{c}\text { S. } \\
\text { No }\end{array}$} & \multirow[t]{2}{*}{ Mangroves } & \multicolumn{4}{|c|}{ Mycelial growth (mm) } & \multicolumn{4}{|c|}{$\begin{array}{l}\text { Per cent inhibition over } \\
\text { control }\end{array}$} \\
\hline & & $5 \%$ & $10 \%$ & $15 \%$ & $20 \%$ & $5 \%$ & $10 \%$ & $15 \%$ & $20 \%$ \\
\hline 1. & Avicenia marina & $28.53^{\mathrm{f}}$ & $26.71^{f}$ & $19.73^{f}$ & $18.23^{\mathrm{f}}$ & 64.33 & 66.61 & 75.33 & 77.21 \\
\hline 2. & Avicenia officinalis & $23.76^{\mathrm{d}}$ & $19.94^{\mathrm{d}}$ & $13.26^{\mathrm{d}}$ & $11.46^{\mathrm{d}}$ & 70.30 & 75.07 & 83.42 & 85.67 \\
\hline 3. & Rhizophora apiculata & $19.42^{b}$ & $15.12^{b}$ & $6.42^{\mathrm{b}}$ & $4.82^{\mathrm{b}}$ & 75.72 & 81.10 & 91.97 & 93.97 \\
\hline 4. & Rhizophora annamalayana & $21.36^{\mathrm{c}}$ & $17.62^{c}$ & $10.92^{c}$ & $9.12^{c}$ & 73.30 & 77.97 & 86.35 & 88.60 \\
\hline 5. & Rhizophora mucronata & $25.21^{\mathrm{e}}$ & $23.39^{\mathrm{e}}$ & $16.42^{\mathrm{e}}$ & $14.91^{\mathrm{e}}$ & 68.48 & 70.76 & 79.47 & 81.36 \\
\hline 6. & Mancozeb 75\% WP @ 0.25\% & \multicolumn{4}{|c|}{0.0} & \multicolumn{4}{|c|}{100} \\
\hline 7. & Control & \multicolumn{4}{|c|}{$80.00^{\mathrm{a}}$} & \multicolumn{4}{|c|}{0.0} \\
\hline
\end{tabular}

Values in the column followed by same letters not differ significantly by DMRT ( $\mathrm{P}=0.05)$

Table.2 Antifungal activity of mangroves at different concentration on growth of $A$. solani $\mathrm{AS}_{5}$ (Agar well method)

\begin{tabular}{|c|c|c|c|c|c|c|c|c|c|}
\hline \multirow[t]{2}{*}{$\begin{array}{l}\text { S. } \\
\text { No }\end{array}$} & \multirow[t]{2}{*}{ Mangroves } & \multicolumn{4}{|c|}{ Mycelial growth (mm) } & \multicolumn{4}{|c|}{$\begin{array}{l}\text { Per cent inhibition over } \\
\text { control }\end{array}$} \\
\hline & & $5 \%$ & $10 \%$ & $15 \%$ & $20 \%$ & $5 \%$ & $10 \%$ & $15 \%$ & $20 \%$ \\
\hline 1. & Avicenia marina & $42.76^{\mathrm{f}}$ & $41.13^{f}$ & $37.24^{f}$ & $35.64^{f}$ & 46.55 & 48.58 & 53.45 & 55.45 \\
\hline 2. & Avicenia officinalis & $28.36^{\mathrm{c}}$ & $26.73^{d}$ & $22.84^{\mathrm{d}}$ & $21.24^{\mathrm{d}}$ & 64.55 & 66.58 & 71.45 & 73.45 \\
\hline 3. & Rhizophora apiculata & $21.58^{\mathrm{a}}$ & $19.95^{\mathrm{b}}$ & $15.96^{\mathrm{b}}$ & $14.46^{\mathrm{b}}$ & 73.02 & 75.06 & 80.05 & 81.92 \\
\hline 4. & Rhizophora annamalayana & $23.42^{b}$ & $21.79^{c}$ & $17.81^{\mathrm{c}}$ & $16.31^{\mathrm{c}}$ & 70.72 & 72.76 & 72.76 & 79.61 \\
\hline 5. & Rhizophora mucronata & $36.41^{\mathrm{e}}$ & $34.78^{\mathrm{e}}$ & $31.09^{\mathrm{e}}$ & $29.29^{4}$ & 54.48 & 61.13 & 56.52 & 63.38 \\
\hline 6. & Mancozeb 75\% WP @ 0.25\% & \multicolumn{4}{|c|}{$7.27^{\mathrm{a}}$} & \multicolumn{4}{|c|}{91.92} \\
\hline 7. & Control & \multicolumn{4}{|c|}{80.00} & \multicolumn{4}{|c|}{0.0} \\
\hline
\end{tabular}

Values in the column followed by same letters not differ significantly by DMRT $(\mathrm{P}=0.05)$

Table.3 Antifungal activity of mangroves at different concentration on sporulation and spore germination of $A$. solani $\mathrm{AS}_{5}$ (Spore Germination Assay)

\begin{tabular}{|c|c|c|c|c|c|c|c|c|c|}
\hline \multirow[t]{2}{*}{ S. No } & \multirow[t]{2}{*}{ Mangroves } & \multicolumn{4}{|c|}{ Sporulation } & \multicolumn{4}{|c|}{ Spore germination $(\%)$} \\
\hline & & $5 \%$ & $10 \%$ & $15 \%$ & $20 \%$ & $5 \%$ & $10 \%$ & $15 \%$ & $20 \%$ \\
\hline 1. & Avicenia marina & +++ & +++ & ++ & ++ & $\begin{array}{l}29.52^{\mathrm{e}} \\
(32.91)\end{array}$ & $\begin{array}{c}26.25^{\mathrm{e}} \\
(30.82)\end{array}$ & $\begin{array}{l}21.41^{\mathrm{e}} \\
(27.56)\end{array}$ & $\begin{array}{l}16.23^{\mathrm{e}} \\
(23.75)\end{array}$ \\
\hline 2. & Avicenia officinalis & +++ & ++ & + & + & $\begin{array}{l}24.46^{\mathrm{c}} \\
(29.64)\end{array}$ & $\begin{array}{l}21.19^{c} \\
(27.40)\end{array}$ & $\begin{array}{l}16.35^{\mathrm{c}} \\
(23.85)\end{array}$ & $\begin{array}{l}11.17^{\mathrm{c}} \\
(19.52)\end{array}$ \\
\hline 3. & Rhizophora apiculata & ++ & ++ & + & + & $\begin{array}{l}19.15^{\mathrm{a}} \\
(25.95)\end{array}$ & $\begin{array}{c}15.88^{\mathrm{a}} \\
(23.48)\end{array}$ & $\begin{array}{l}11.04^{\mathrm{a}} \\
(19.40)\end{array}$ & $\begin{array}{c}5.86^{\mathrm{a}} \\
(14.00)\end{array}$ \\
\hline 4. & Rhizophora annamalayana & ++ & ++ & + & + & $\begin{array}{l}21.75^{\mathrm{b}} \\
(27.79)\end{array}$ & $\begin{array}{c}18.48^{b} \\
(25.46)\end{array}$ & $\begin{array}{l}13.64^{\mathrm{b}} \\
(21.67)\end{array}$ & $\begin{array}{c}8.46^{b} \\
(16.90)\end{array}$ \\
\hline 5. & Rhizophora mucronata & +++ & +++ & ++ & ++ & $\begin{array}{l}28.48^{d} \\
(32.25)\end{array}$ & $\begin{array}{l}25.21^{d} \\
(30.13)\end{array}$ & $\begin{array}{l}20.37^{d} \\
(26.82)\end{array}$ & $\begin{array}{l}15.19^{d} \\
(22.93)\end{array}$ \\
\hline 6. & Control & \multicolumn{4}{|c|}{++++} & \multicolumn{4}{|c|}{$80.00^{f}$} \\
\hline
\end{tabular}

Values in the column followed by same letters not differ significantly by DMRT $(\mathrm{P}=0.05)$

Sporulation: excellent- ++++; good-+++; fair-++; poor-+ 
It has well documented that leaf extract of $D$. stramonium, Eucalyptus oblique and Allium sativum are effectively inhibits the mycelial growth of $A$. solani under in vitro condition (Nashwa et al., 2012; Sadana and Didwania 2015; Pankaj Kumar and Singh 2017).

\section{References}

Baka ZAM (2010) Antifungal activity of six Saudi medicinal plant extracts against five phyopathogenic fungi. Arch Phytopathol Plant Prot. 43:736-743

Bandaranayake WM (2002) Bioactivities, bioactive compounds and chemical constituents of mangrove plants. Wetlands Ecology and Management 10:421-52

Behbahani BA, Yazid FT, Shahidi F, Riazizahedan F (2016) Antifungal effect of the aqueous and ethanolic Avecinnia marina extracts on Alternaria citri and Penicillium digitatum. Journal of Research in Medical Sciences 18(2):2933

Bose S, Bose A (2008) Antimicrobial activity of Acanthus licifolius. Indian J of Pharm Sci 70:821-823

Chandrasekaran M, Kannathasan K, Venkatesalu V, Prabhakar K (2009) Antibacterial activity of some salt marsh halophytes and mangrove plants against methicillin resistant Staphylococcus aureus. World J Microb and Biotec 25:155-160

Chang SJ, Chang YC, Lu KZ, Tsou YY, Lin CW (2012) antiviral activity of Isatis indigotica extract and its derived indirubin against Japanese encephalitis virus. Evid Based Complement Alternat Med doi: 10.1155/2012/925830. http://dx.doi.org/10.1155/2012/925830

Hosein E, Azar S, Parivash K, Alireza B, Mansour B, Leila S (2010) antifungal effect of Zataria multiflora: an in vitro Evaluation. Global Veterinaria, 4:140-
143

Indian Horticulture Database (2017) Natinal Horticulture Board, Department of Agriculture

Jones JB, Jones JP, Stall RE, Zitter TA (1991). Infectious antifungal. Plant Physiology, 108: 17-27

Kepenekçi I, Sağlam HD 2015 Extracts of some indigenous plants affecting hatching and mortality in the root-knot nematode [Meloidogyne javanica (Treub) Chitwood] Egyptian Journal of Biological Pest Control 25: 39-44

Kordali S, Usanmaz A, Cakir A, Cavusoglu A, Ercisli S (2013) In vitro antifungal effect of essential oils from Nepeta meyeri Benth. Egyptian Journal of Biological Pest Control, 23: 209-213.

Mathur K, Shekhawat KS (1986) Chemical control of early blight in Kharif sown tomato. Indian Journal of Mycology Plant Pathology 16: 235-238

Mehdi F, Imran Ali Siddqui, Assia Sajjad, Muhammad Afzal (2000) Effects of Rhizophora mucronata (Mangrove) in the Control of Root-knot Nematode and Root-infecting Fungi of Tomato. Pakistan Journal of Biological Sciences 3(8):1308-1310

Mehdi FS, Siddiqui IA, Erum S, Ali R (1999) Effect of Avicennia marina and Paecilomyces lilacinus on rootrotrootknot diseases of tomato. Pak $\mathrm{J}$ Biol Sci 2:1462-1466

Muthukumar A, Naveenkumar R, Venkatesh A (2014) Efficacy of water extracts of some mangrove plants for eco-friendly management of root rot disease of groundnut. Journal of plant pathology \& Microbiology 5:243

Narender Kumar, Sushma Nema, Vibha, Ratan Lal Sharma (2017) Effect of fungicides and plant extracts on the sporulation and spore germination percent of $A$. sesame. International Journal of Chemical Studies 5(4):297-299 
Nashwa SMA, Abo-Elyousr KAM (2012) Evaluation of various plant extracts against the early blight disease of tomato plants under greenhouse and field conditions. Plant Protect. Sci., 48: 74-79

Pankaj Kumar, Singh S (2017) In Vitro Evaluation of Fungicides and Plant Extract against Alternaria solani (Ellis) Causing Early Blight in Tomato (Lycopersicon esculentum Mill.). Int. J. Curr. Microbiol. App. Sci. 6(9): 820827.

doi: https://doi.org/10.20546/ijcmas.2017.60 9.101

Raji R, Raveendran K (2013). Antifungal activity of selected plant extracts against phytopathogenic fungi Aspergillus niger. Asian J Plant Sci Res. 3:13-15

Rastegar S, Gozari M (2016) Antioxidant and antifungal activities of two species of mangrove plant extract. Journal of Coastal Life Medicine 4(10):779-783

Sadana, D. and Didwania, N. (2015) Bioefficacy of fungicides and plant extracts against Alternaria solani causing early blight of tomato. International Conference on Plant, Marine and Environmental Sciences
(PMES-2015) Kuala Lumpur (Malaysia). Pp. 38-42

Selvam KA, Kolanjinathan K (2014) Antifungal activity of mangrove medicinal plants against Candia albicans and Candida glabrata. Int $\mathbf{J}$ Curr Res Chem Pharma Sci., 1(9):231236

Shekhawat P, Prasad R (1971) Antifungal properties of some plant extracts. Inhibition of spore germination. Indian phytopathol 24:800-802

Taskeen-Un-Nisa, Wani AH, Bhat MY, Pala SA, Mir RA (2011) In vitro inhibitory effect of fungicides and botanicals on mycelial growth and spore germination of Fusarium oxysporum. J Biopesticides. 4:53-56

Thongson CPM, Maha Karchnakul W, Weijs J (2004) Antimicrobial activity of ultrasound assisted solvent-extracted spices. Letters Appl Microbial 39:401404

Vengadeshkumar, L. (2017) Studies on the effect of plant products and Biocontrol agents against BLB of paddy caused by Xanthomoanas oryzae pv. oryzae Ph.D., thesis Annamalai University, Annamalai Nagar, Chidambaram

\section{How to cite this article:}

Mahalakshmi, G., L. Vengadeshkumar, S. Sanjaygandhi and Mary Sharmila, A. 2020. Inhibitory Effect of Marine Mangrove on the Growth of Alternaria solani Causing Tomato Early Blight Disease. Int.J.Curr.Microbiol.App.Sci. 9(04): 2196-2202. doi: https://doi.org/10.20546/ijcmas.2020.904.263 